Sex Education, 2, 2

2002 pp. 171-182

What are Little Boys Made of, Made of? Victorian art and gender identification.

Nicholas Addison

Abstract: $\quad$ Given that educators increasingly have to integrate social and moral education within the general curriculum, this paper considers ways in which the visual arts may or may not be a useful resource for challenging the stereotypical preconceptions about gender and sexual identity held by many people in a post-industrial, intercultural society. Focusing on Tate Britain's inaugural exhibition for the opening of its new galleries, 'Exposed: the Victorian Nude', the paper examines a selection of artefacts that are assumed to represent the sexual mores of Britain at a pivotal time in the construction of its national identity. With reference to the social history of art and feminist theoretical 'interventions', the exhibits are analysed as possible evidence of the Victorians' 'skills, beliefs and values about sexual relationships, identity and intimacy' the lifelong study of which provides the Sex Education Forum (1997:1) with a definition of sex education. Subsequently two questions are posed: firstly, what does the exhibition's selection and hang say about contemporary beliefs? Secondly, can historical artworks be constructively used with young people (post-16) as a catalyst for discussion of sex, gender and sexuality?

\title{
Art in Education
}

Recent reports echo the government's drive to position the museum as a significant resource for education (Anderson 1997; Robinson 1999) and, by extension, the consolidation of a national, cultural identity. It is assumed that familiarisation with these privileged artefacts (many of which are categorised as art) and the discourses that surround them can provide the populace with material evidence of the nation's cultural, moral, social and spiritual values; an embodiment of its 'normative order' (Foucault 1977). Often it is the Art \& Design educational visit that first facilitates this process of acculturation. In primary and secondary education art is usually defined as a distinct and privileged category that transcends the ways in which other forms of visual and material culture are referenced, presented and assessed. The cultural concepts reproduced through this process depend on a history of patriarchy, individualism and western domination (Nochlin 1988), concepts that are notably reinforced in the fine art gallery where the 'best' and most authoritative artworks (the canon) are paraded as a manifestation of the creativity of the western, male genius. Inevitably, few artists come to stand in for this type of 'being' and in secondary education they are usually chosen from two European canons, classical and/or modernist. The nude, respectively male and female, is central to the aesthetic practices and ideological formations of both (Duncan 1979; Nead 1992). Therefore the nude, like any other artwork, is saturated in, and productive of meaning, meaning that cannot be confined to the work in itself. However, enquiry into the ways art produces meaning is notably absent in secondary education (Hughes 1999), even the traditional modes by which it is addressed: aesthetic appreciation, formal analysis, iconography, fall outside everyday speech and are frequently bypassed. When it comes to a social history of art and its quest to: 'discover what concrete transactions are hidden behind the mechanical image of 'reflection', to know how 'background' becomes 'foreground'; [and] instead of analogy between form and content, to discover the network of real, complex relations between the two' (Clark 1973: 12) such a detailed and rigorous approach rarely surfaces in the education of young people. Yet it is in these transactions and relations that some sense of a people's beliefs and values might be sought. 
Although Victorian art has been within the domain of the social art historian for a generation, it is frequently avoided in secondary art education because it is condemned as sentimental and kitsch; few works represented in this exhibition fall within any non-British canon. If the Sunday school once inculcated the young child of empire and Commonwealth into its conventions, both 'at home and abroad', such a role is now transferred to the plush birthday card and Hollywood blockbuster. These conventions, verisimilitude, didactic narrative, allegory, are thus still in use, albeit transmuted through the medium of cinema, and quickly absorbed on many levels; this legacy makes Victorian art an accessible, if dangerously naturalised, historical resource. The problems arise when art is made to serve as mirror, as if it denoted literally the habits and customs of an age ("the mechanical image of "reflection"). Visual representation may reflect aspects of social practice but is itself a part of discourse, that 'network of real, complex relations' and 'concrete transactions' and can produce social practice. How, when and where art is displayed and the way it is discussed may reveal more about the people for whom it was made than the represented objects themselves; indeed what is not shown, the absences and lacunae, may indicate those issues about which they feel most uncomfortable. Equally, what is shown, particularly when 'others' are being represented, may well turn out to be a projection of those same issues, a disavowal that invests the other with the very traits that a culture most fears about itself. It is also important to ask who is doing the representing? Can the views of one group of professionals (artists) mediating representation for a particular public (art lovers) stand in for the typical values of their whole culture? What are the subject-positions from which these representations are made?

Victorian art and the subject position of representation

Public nudity in Victorian Britain (even partial nudity) was base, a sign of otherness. For the bourgeoisie it signalled the working classes and the 'residuum' whereas for the British people it was a sign of other 'races', context determining when and where such a state, however regrettable, was acceptable. In contradistinction, the nude, ubiquitous in the form of white marble sculpture, was an elevated phenomenon that could lead the 'educated' viewer away from base thoughts towards a contemplation of the ideal. This ideal was suitably and of necessity divorced from the lived experience of those whose lives it would inform. Consequently the human body could only be represented in two contexts; one, art, where it was legitimised as the 'nude' and two, science, where it functioned as the 'specimen'. Lord Clark's influential distinction from the 1950s echoes the sentiments of many educated Victorians: 'To be naked is to be deprived of our clothes... The word nude, on the other hand, carries, in educated usage, no uncomfortable overtone. The vague image it projects into the mind is not of a huddled and defenceless body, but of a balanced, prosperous and confident body: the body re-formed' (1985:1). With this binary opposition, naked/nude, Clark establishes an elevated, moral position from which to look at the body. Pointon (1990: 11-12) and Nead (1992) propose that this opposition, reinforced by others such as mind/body, art/obscenity, is typical of the hegemonic tools employed by Clark's assumed spectator, the 'male, heterosexual connoisseur' (ibid: 13). In many ways it is he who exemplifies the educated Victorian, middle-class male and who takes the privileged subject-position of this tale. Without some insight into the ways in which these oppositions constructed his tastes and values and insinuated themselves into his sexual identity, the Victorian nude may come to seem unduly contradictory. As Nead points out in her examination of the female nude: 'in the main it has worked to legitimise patriarchal views of femininity whilst claiming to be set apart from the daily political concerns of society' (p. 55). ). Before examining both the exhibition and the effects of patriarchal hegemony it is important to establish how the nude, under the control of the middle class Victorian male, was increasingly made to personify the polarised extremes of virtue and vice. 
The nude in Victorian art: what is shown

Two differing cultural and intellectual traditions of great authority dominated all forms of pedagogic discourse in Victorian England, the Christian and the classical and throughout the period they were in constant dialectical relationship. Matthew Arnold clarified their difference in 'Culture and Anarchy' (1862): 'the uppermost idea of Hellenism is to see things as they really are; the uppermost idea with Hebraism is conduct and obedience. Nothing can do away with this ineffaceable difference' (in Hersey 1996: 67). Moral values were profoundly conditioned by Christian, particularly Protestant, teaching in which the unmediated naked body, 'defenceless' and usually female, was a dangerous and transgressive sign signifying sex (of course in the Catholic tradition the male nude was everywhere apparent in the incarnation: 'the supreme joy of the newly arrived soul [into heaven] will be the beauty of the body of Christ, unclothed on the cross' [Bellarmino in Ibid: 25]). The church prescribed sexual practice itself by providing a simple binary code where certain forms of sexuality were authorised (procreative sex within marriage) and others proscribed (everything else); in this way respectively, normal and perverse practices were defined, and in alliance with the corrective technologies of science (psychiatry, manufacture, and the penal system [Foucault 19//]) regulated. In contradistinction ethical values were profoundly conditioned by classical culture (particularly Greek) where the naked body, perfect and male, signified the ideal, a personification of the 'democratic' body politic, an all male, homosocial collective. Thus, for the Victorians the nude had come to signal ancient Greek culture which had in turn come to embody learning and virtue (Jenkyns 1992). Whereas the church was continuously troubled by the relationship between art and public morals and at times campaigned against high art's appropriation of the body $(\mathbf{m m m})$ the secular institutions of the state were increasingly to deploy it with equanimity. For a Christian people, the distaste or desire that the body unadorned must threaten could only be contained through the transformative power of culture.

From the mid-eighteenth century onwards the British establishment self-consciously attempted to develop a national school and inevitably artists adapted the grand historical traditions of European art. But with idiosyncratic exceptions they failed to achieve their aim developing instead landscape and portraiture along diverging paths; the nude was rare. Not so in France, where, during the revolution and Napoleonic era, the neoclassical male nude embodied the fraternal ideal. But 'in establishing maleness as the emblem of (ideal) humanity, and relegating femaleness to the realms of alterity, difference, and corporeality (the body itself), classical art styles promote a dichotomy that affirms the equivalence of "Man' with "human" and all that that implies' (Solomon-Godeau 1997: 13). Already within the value systems of the middle classes sexual difference had been accentuated, and in bourgeois dress, the colour, flamboyance and narcissism of male aristocratic display was rejected. By the nineteenth century men donned relatively sober garb, whereas women came increasingly to be 'confectted' as 'specular objects of desire'. It was no longer seemly to view a man as an object of beauty, nude or clothed, whereas it became a duty to view a woman in such a way: 'the domain of specularity, exhibitionism and display comes therefore to be designated and identified as the domain of femininity' (ibid: 216). Thus by the time of Victoria's accession (1837) the female nude had come to supplant the male as the appropriate vehicle for scopophilic contemplation and in municipal squares and parks she was gradually introduced as sculpture to personify the virtues of peace, the arts, industry and so on. Early Victorian sculptors like Foley saw no irony in entitling a female nude 'Innocence' (1847) and disseminating her widely for domestic display as (white) Copeland ware (Jenkyns 1992:104). Colour, however, signalled a less chaste more sensual world, and the Victorians were always more troubled by the painted nude. 
The exhibition

It is not surprising that at the start of Victoria's reign, with its Anglo-German axis and antiFrench agenda, the nude, a necessary sign of civilization, required an English pretext, and it was literature not history that proved the most useful reference. The first room of the exhibition takes the establishment of the 'English Nude' as its theme and it is here that Lady Godiva's selfless and thus moral act of exhibitionism is pitted against the polymorphous perversities of Titania and her entourage. Viewers who gazed approvingly at, for example, Landseer's portrayal of Godiva's virtue (1865) placed themselves in the unenviable position of 'peeping Tom' whose potentially masturbatory voyeurism results in his blindness (see Tennyson's interpretation of the legend, 1842). The moral viewer, worried by this paradox, could turn to Rejlander's early photographic essay for guidance which makes explicit 'The Two Ways of Life' available to the young Victorian male (1857).

A more elevated, abstract nude appeared at the instigation of a new generation of artists, who, training on the continent, were able to insinuate a grand and 'pagan' version despite the attacks of religious proselytisers and feminists //. Leighton exemplifies this attempt and his suitably lofty manner was later to appeal to those wishing to impose a style appropriate for Empire, just as classical architecture was to win out over gothic when Britain embodied itself abroad. This supposedly Greek manner (Phidias, Polylkleitus and Praxitales were the models) was meant to provide the nude with a nobility befitting the public domain, perhaps even to reflect the racial superiority of a people born to conquer. It is the public/private dichotomy that provides the curators with an opposition between rooms two and three, 'The Classical' and 'The Private' Nude. Interestingly, there are no works in the exhibition that are Biblical in theme despite significant nudes of this kind by Hunt 'The Shadow of Death' 1871 and Leighton's own 'Elijah in the Desert' 1876. As a matter of fact Leighton was profoundly anti-semitic and in his lectures as President of the Royal Academy (published 1893) he railed against the Judaeo/Christian tradition for its repression of both visual representation and the naked body. The physical type that Leighton configured in his art was strictly Ayran and, as he made explicit in his lectures, he believed the nation itself was forging an Ayran elite; life was imitating art. After discussing the origins of the Aryan ideal in Greek art he told his listeners, mostly students, mainly men, that they should not only take up physical culture but should choose their partners wisely: 'a new ideal of balanced form wholly Aryan [is] found in the women of another Ayran race - your own (in Hersey 1996: 72).

Far from limiting the representation of the nude from other areas of visual culture it seems that the visibility of the nude in high art and the debates this encouraged are shown to have proliferated its reproduction in other forms. The nude is given its 'private' but popular presence in an extension to room three where illustrations, photographs and films serve to exemplify the different motivations and intentions of makers; from depictions of innocence and beauty (men, women and children) to illicit forms of titillation and pornography; as the catalogue informs: 'the trade in sexualised images of children was merely an adjunct to the trade in bodies' (Smith 2001:168) and it should be remembered that mid-Victorian London was the capital of child prostitution in northern Europe. In addition the age of consent was only increased from 12 to 16 in 188?, at the time much to the despair of the Tory party. Some of the paintings in room three, equally seductive thematically and functionally, had in fact been shown publicly, but censored. For example Burne Jones's 'Phyllis and Demopfoon' (1870) depicts two lovers in a fugitive embrace; Demopfoon's genitals, although in shadow, are exposed and central to the composition. Despite the fact that their visibility was itself cause for concern, their size was even more troubling. Conforming to the classical convention Burne-Jones provides him with small genitals, and this reduction from nature, overlooked for nearly two thousand years, was perceived 
by the Victorians as unmanly (ibid: 142). According to Bryson (198) this diminution serves to resolve the anxiety of male viewers caused in the inevitable act of comparison: 'as the sculpture's genitals are diminished relative to actual genitals, so the sense of the male's genital self possession and sexual power stands in relation to the masculine imago' (p.235). The phallic status that the male nude possesses in classical art is not an attribute of his penis, rather his potency is displaced on to accessories such as swords, clubs or absurdly animated drapery which alone can signify the power of the phallus and its symbolic role within patriarchy (for an elaboration of this point and a discussion of Lacan's distinction between the phallus and the penis see Solomon-Godeau 1997: 177-185). For Pollock (1988) the oppulent bower that surrounds Rossetti's 'Venus verticordia' (1864-8) likewise acts as a displacement of the genitals: 'Sexuality is vividly represented but in a displaced and over anxious profusion of honeysuckles and roses which distract, mask but signal what cannot be shown' (p. 138). In room four, with the myth of Pygmalion, the artist attempts to overcome such anxiety by taking complete control of the object of desire; Pygmalion, disgusted by the corporeality of real women, animates his own ideal sculpture, his muse, without which his creativity is stifled. For many social historians such anxiety signals a crisis in masculinity (Roper and Tosh 1991); the symbolic work that the Victorian nude therefore came to offer was a reassertion of masculine authority, but this it frequently failed to achieve.

It is Pandora about to open her box who mediates the entrance to room five, 'Sensation! The Nude in High Art'. Here the spectator is assailed by a series of grand machines in which women are depicted as hybrids confabulated somewhere between the ideal body and the naturalistic portrait. Still bereft of body hair they die as martyrs or pose as personifications of nature and the virtues, but increasingly they vamp it up as temptresses, from Lilith to the sirens, a codification of the type of women who in life, prostitutes, were held responsible for corrupting the morals of the nation and sapping the strength of its youth. The 'moral panic' that developed around discourses on the body in the 1880s was a result of the reports on prostitution that fuelled reform in the 1885 and subsequently 1898 Criminal Law Amendments Act and for Nead (1992: 105) they prefigure similar debates in the 1970s although these shift from the regulation of actions to the regulation of representations. It is also in 'Sensation!' that racial difference is most prominently announced. In Normand's vast 'Bondage' (1895) Rhameses II consults with his wife as he chooses from amongst a trio of potential concubines: one, a 'Nubian slave', is portrayed brazenly confident before the patriarch's gaze while a mother and daughter, the palest of Europeans, indeed as blond and blushing as the sunlight itself, turn from him in fear and shame. In this way the dominant Victorian belief in absolute racial difference is demonstrated, a belief conditioned by the physiognomic codifications of Linnaeus (1735) and his followers and the more recent theories of polygenism and environmental degeneracy (see Poliakov 197: 164-167): 'the more an organ extends, the more powerful and active it becomes, in like manner, the more it contracts, the more it loses its activity and power. Hence, it follows that if the brain contracts, and the nerves emerging from it expand, the negro will be less inclined to think, than to abandon himself [sic] to sensual pleasures whilst the reverse will be remarked in the white' (Virey 1824 in Honour1989: 18). In Normand's, and in other paintings not in the exhibition, the overt sexuality of blacks is contrasted with the natural modesty and reflectiveness of whites. This fetishisation of the other, signalled here by skin colour and posture, is a common disavowal in orientalist texts, a 'strategy by means of which a powerful fascination or desire is both indulged and denied. It is where what has been tabooed nevertheless manages to find a displaced form of representation' (Hall 1997: 267). This blatant process of colonialist 'othering' indicates here the hallucinatory, omnipotent fantasies of men, but it simultaneously highlights Victorian fears about the threat of 'racial pollution' through miscegenation (Coombes 1994: 90-91). 
Both rooms entitled 'the Modern Nude' show nudes stylistically and conceptually opposed to the grand style and once again inspired by continental example. Perhaps the female nudes by Gwen John, Sickert, et al in the first room, many Edwardian, mostly muted, introspective and urban, seemed too dispiriting for the curators who end the show back in the late Victorian sunlight with Steer, Sargent and Tuke, only Stott straddling the divide. It is the shining Aryan health of the High Victorian female nude that disintegrates in the former room, whereas in the final, the gleaming bodies of youths makes explicit for the curators (see the wall texts) the undertow of homoeroticism that has surfaced in pockets throughout the exhibition.

If, for the Victorian, the nude is predominantly a symbolic category, despite the naturalistic credentials of the last two rooms, the modern viewer is unlikely to find the social and sexual behaviours of the era mirrored on the walls. The nude, evidently an unstable and mutable category, has been shown to play an emblematic role in the construction of national and gendered identities. This selective analysis has given clues to the attitudes and values of its makers and the way in which discourses on gender, sex and sexuality are inextricably bound to discourses on class and race. In relation to gender and sexuality, and the subject-position of the male artist, what further contextual information might help the modern viewer make sense of the complex relations between form and content in these works, with their disavowals and displacements?

Masculinity in Victorian society: what is not shown

At the start of Victoria's reign (1837-1901) the typical middle class father spent time with his children, displaying concern and physical affection (Tosh 1991). It was not until the 1850s that the stereotypes of the formidable patriarch and the disinterested, stiff upper-lipped gentleman make their appearance; their counterparts, the sensitive, asexual mother and the hysterical, unmarried daughter likewise emerge. These personas were partly the result of the separation of public and domestic spheres brought about by rapid industrial, colonial and bureaucratic expansion. In official histories the hypervisibility of the male types was the result of the concerted attempt by men to eradicate women from all texts: 'The historians who came after him echoed Carlyle's preoccupations, not only by excluding women from the public record, but by elevating the "public" man as the object of study while entirely submerging his gender identity' (Roper and Tosh 1991:1). The social identities of men and women were thus polarised and feminine influence on boys was gradually reduced. Accordingly anxiety in middle class males was the result of harsh regimes instigated by fathers who realised that a good profession was now dependent on hard work rather than patronage. Boys were sent to public school from the age of ten and this early induction into a bachelor ideology was perpetuated in the universities, professions, club culture and empire.

From the eighteenth century onwards, a regime similar to that regulating the social behaviours of Victorian children had already been applied to their sexual lives:

a panic theme appears... Children masturbate. Via the medium of families, though not at their initiative, a system of control of sexuality, an objectivisation of sexuality allied to corporal persecution, is established over the bodies of children. But sexuality, through thus becoming an object of analysis and concern, surveillance and control, engenders at the same time an intensification of each individual's desire, for, in and over his body. The body thus became the issue of a conflict between parents and children, the child and the instances of control (Foucault 1980: 56-57). 
In the Victorian family this repressive regulation of the previous century was bolstered by repressive and punitive technologies, particularly those directed at boys (fig 1) and it is not surprising that subsequently many men found it difficult to identify their masculine self-image with tender or affectionate feelings. As a result it was quite common for the sexual practices of men to be split between the social requirement to procreate with an obedient and companionable spouse and to find sexual gratification with 'others' less constrained by propriety; the two types are everywhere manifest in this exhibition and whether historical or allegorical they are always a projection of fantasy. In reality these 'others' were those people who were economically and culturally powerless before the middleclass male, that is working class and colonised, men, women and children: 'Just as the various colonial possessions... were useful as places to send wayward sons, superfluous populations of delinquents, poor people, and other undesirables, so the Orient was a place where one could look for sexual experience unobtainable in Europe' (Said 1978: 190). Just as the woman forced into prostitution was blamed for corrupting the nation, rather than the patriarchal structures that determined her work, so too the presumed sexual excesses of colonised peoples were theorised as natural and, after Darwin's 'The Descent of Man' (1872), the cause of degeneracy.

Despite these inducements to violent fantasy and predatory status, within urban culture gentlemanly codes ensured that men's behaviour was nonetheless publicly decorous. But there was a fear that if a man was allowed to become over-urbanised, nurtured on gentility and bureaucracy, he would become feminised. The epicene and effete caricature of the aesthetic dandy of the last quarter of the century, exemplified in Wilde and notably lampooned in Gilbert and Sullivan's 'Patience' (18) was the unwelcome outcome of such feminisation. The panic over the state of the nation's morals in the 1880s was particularly fuelled by homosexual scandal and, 'for the social-purity people it was lust which threatened both the family and national decay: "Rome fell; other nations are falling; and if England falls it will be this sin, and her unbelief in God, that will have been her ruin"” (in Weeks 1990; 18).

Sport was the means by which masculinity could be recuperated and a new regime of physical exercise joined the others so as to produce not only a prosperous body but a healthy one too. The virtues of good health, mind and morals were conflated in the sign of the athletic body. In 1867, for William Acton, this body signalled disciplined purity: 'the effect of exercise in diverting the activity of the genital organs into other channels was known to the ancients, who, with their very numerous gymnasium, could not fail to remark the continence of the athletae. It is likewise a well-known fact that those who are obliged to undergo great physical exertion are remarkable for their abstinence from sexual pleasures' (in Smith 1996: 138). The team sports of public school ensured that this body functioned within an ethical framework but also made it receptive to more narcissistic forms of development, and by the end of the century the athletic body signalled muscular Aryan potency. The various panegyrics to the beauty of the active, adolescent male produced by Tuke might in the homosocial space of athleticism, make 'the male body a legitimate object of a male's gaze' (Hatt 1993: 63) so that the homoeroticism noted by the curators would never consciously have to be acknowledged. This was certainly already the case in popular culture where one of the founders of modern body building, Eugene Sandow (nee Muller), entertainer and pedagogue, exhibited his perfected body to admiring audiences in the USA (1893) and Britain. Such was his popularity that he became one of the richest men in the world and later to George V. The clear genealogical link between the academic nude, Sandow and the muscle Marys of today's beach and gay culture would have bemused the Victorians for whom the stereotypical homosexual, a term first coined in 1885, was fey and effeminate. The only notable artist who had been publicly humiliated and punished for this crime before Oscar Wilde was Simeon Solomon (respectively 1873 and 1895), whose androgynous ideal (Love in Autumn 1866) did not conform to the athletic type. This isolated instance prefigured the very real panic of the 
'fin de siecle' when the normative order of “"obligitory heterosexuality" built on male dominated kinship systems [and] the homophobia which is a necessary consequence of such patriarchal institutions as heterosexual marriage' (Kosofsky 1985: 3) was threatened by feminist challenge and male anxiety. The result in young men was 'the refusal to marry and the flight from domesticity' (Tosh 1991: 67). It could be argued that it was art that produced the armoured body of the muscle man, the antithesis of the domesticated gentleman of early Victorian Britain. The former exemplifies an almost hysterical hypermasculinity, fashioning a body that is less a protection from external threat than a means to contain internal psychic disintegration, a means by which the masculine ego/body might pertain to the condition of the phallus (Theweilet 1989: 7). Such male anxiety is even more worrying if one considers the culmination of this physique in the sculptural megalomania of Nazi Germany, where, although nudity in life was outlawed, the 'nude', in union with his spouse and twin, would engender a race of phallic warriors.

A pedagogical resource

It is through an analysis such as this, inevitably selective and reductive due to space, that the Victorian nude might be a vehicle through which the modern viewer can come to question the values (including pedagogic) of its makers, and, through comparison, question the values embodied in contemporary representations of the nude. Although a cyclic view of history is suspect, the parallels between Victorian and Elizabethan 'fin de siecles' suggest a continuum, a residue that although mutated, is worryingly persistent. This poses some challenging questions for contemporary educators to discuss with their students: what is the relationship between the social purity movement (1880s) and the Festival of Light (1970s), the feminist movements from 1880 and from 1970? - why are there similarities between the Aryan goddess and the super model, the phallic warrior and the X Men? - is there any relationship between eugenics and cloning? - colonial rape and sexual tourism? - the African villagers exhibited at colonial trade fairs (oddly nowhere in this exhibition) and the hypervisibility of the black athlete in advertising? Differences are no doubt as numerous as correspondences but the one essential similarity is patriarchy and its reproduction through the apparatuses of the state, commodification and the heterosexual family. Is the current 'crisis in masculinity' producing re-assertions of equally dubious psychological benefit? 'Exposed: The Victorian Nude' is marketed both as a contribution to debates about the way national identity has been constructed and as an expose of Victorian sexuality which was, so the curator Alison Smith assures us, far from the stereotype of prudery. If this stereotype is exploded by the exhibition the extent to which Victorian disavowals are exposed is questionable. Although the relationships between art and eugenics, art and gender politics, art and racism are referenced, this particular 'thematic' hang evades these issues, and it is probable that without recourse to the catalogue any non-specialist educator accompanying a student group would bypass so veiled an exposure. As many journalists' reviews indicate, the viewer seems to be invited to /II/. The disavowals of the Victorians are not identical to those of today where surely the taboo over the erection is second only to the hysteria around representations of the nude child? But the distance provided by historical artefacts may enable discussion of current taboos and a platform from which sexuality can be discussed without a prurient or proscriptive agenda.

These taboos are not peculiar to the visual arts but permeate all aspects of visual culture. Additionally such prohibition has an impact on behaviour itself and the way that the transgression of taboos, in practice and in representation, is judged by others. The production and reception of art therefore needs to be approached as something within, not apart from social discourse. If art is to be used within a constructivist view of learning the educator must attempt 'to dispense with the constituent subject, to get rid of the subject itself, that's to say, to arrive at an analysis which can account for the constitution of the subject within a historical framework' (Foucault 1980: 
117). By means of such an analysis educators might enable their students to consider the 'self' as something constructed within the 'normative order', a realisation that would help them understand that their judgements of their own and others' sexual identity, conforming or opposing prevalent norms, are not the product of the timeless laws of nature but are produced within a specific cultural and historical moment. Although the body in contemporary visual and material culture may be endlessly exploited for its erotic potential, a potential that is sometimes disavowed or sublimated in the nineteenth century nude, different taboos are currently being disavowed in representations of the body. In the Victorian era the subjectivities of 'little boys and girls' were undoubtedly formed in relation to the contingent laws of the father; one has to ask, has so very much changed?

References

Anderson, D. (1997) A Common Wealth, London: Department of National heritage

\section{Bryson, N. et al (198) Visual Culture}

Clark, K. (1985) (first published 1956) The Nude, London: Penguin

Clark, T. J. (1973) Image of the People, London: Thames and Hudson

Coombes, A. (1994) Reinventing Africa, New Haven and London: Yale University Press

Foucault, M. (197/) The History of Sexuality Part 1, London: Penguin

Foucault, M. (1977) Discipline and Punish: the birth of the prison, London: Penguin

Foucault, M. (1980) Power/Knowledge, Hemel Hempstead: Harvester Wheatsheaf

Golby, J. M. (ed) (1986) Culture \& Society in Britain, Oxford University Press

Hall, S. (ed.) (1997) Representation, London: Sage in association with the Open University

Hatt, M. (1993) '’ In K. Adler and M. Pointon (eds.) The Body in Question

Hersey, G. L. (1996) The Evolution of Allure, Cambridge, Mass. and London: MIT Press

Honour, H. (1989) The Image of the Black in Western Art, IV, Harvard University Press

Hughes, A. (1999) 'Art and Intention in Schools; Towards a New Paradigm' Journal of Art and Design Education 18, 1.

Jenkyns, R. (1992) Dignity and Decadence, London: Fontana Press

Nead, L. (1992) The Female Nude: Art, Obscenity and Sexuality, London: Routledge

Nochlin, L. (1988)

Poliakov, L. (1977) The Aryan Myth, Meridian 
Pollock, G. (1988) Vision and Difference, London: Routledge

Robinson, K. (1999) All Our Futures: Creativity, Culture \& Education, London: DfEE \& NACCCE

Roper, M. and Tosh, J. (eds.) (1991) Manful Assertions, London: Routledge

Said, E. (1978) Orientalism, Harmondsworth; Penguin

Sex Education Forum (1997)

Smith, A. (1996) The Victorian Nude, Manchester University Press

Smith, A. (ed.) (2001) Exposed: The Victorian Nude, London: Tate

Solomon-Godeau, A. (1997) Male Trouble: A Crisis in Representation, London: Thames and Hudson.

Theweilet, K. (1989) Male Fantasies, Vol 2, Polity Press

Tosh (1991) 'Domesticity and Manliness in the Victorian Middle Classs' In M. Roper, M and J. Tosh, (eds.) op. cit.

Weeks, J. (1990) Coming Out, London: Quartet 